\title{
Amniotic Membrane as a Scaffold for Periodontal Tissue Engineering
}

\author{
Asrar Elahi, M.Sc. ${ }^{1}$, Haslina Taib, M.Clin.Dent. ${ }^{2}$, Zurairah Berahim, Ph.D. ${ }^{2}$, \\ Azlina Ahmad, Ph.D. ${ }^{3}$, Suzina Sheikh Ab Hamid, M.Med. ${ }^{4}$ Nurfarah Aini Mocktar, B.A.S. ${ }^{2}$ \\ 'Department of Periodontics, College of Dentistry, Lahore Medical and Dental College, Lahore 53400, Pakistan. \\ ${ }^{2}$ Periodontics Unit, School of Dental Sciences, Universiti Sains Malaysia, Kubang Kerian, Kelantan 16150, Malaysia. \\ ${ }^{3}$ Molecular Biology Unit, School of Dental Sciences, Universiti Sains Malaysia, Kubang Kerian, Kelantan 16150, Malaysia. \\ ${ }^{4}$ Tissue Bank, School of Medical Sciences, Universiti Sains Malaysia, Kubang Kerian, Kelantan 16150, Malaysia. \\ Received 2 March 2020 •Revised 16 June 2020 • Accepted 21 June $2020 \bullet$ Published online 2 November 2020
}

\begin{abstract}
:
Periodontal disease is characterized by the destruction of tooth supporting structures, and continuous destruction of these structures may lead to alveolar bone defects and tooth loss. Periodontal therapy aims to arrest the disease progression as well as to regenerate the loss of structures. Since, the regeneration of these structures is a complex process, cell-based tissue engineering has become one of the methods for periodontal tissue regeneration. In order to give mechanical support to the cells, an amniotic membrane has been proposed as one type of periodontal scaffold, due to its predictable properties. In this review, the integral structure, properties and the recent research in application of amniotic membranes, basically in medical and dental surgeries, along with its potential as a scaffold in periodontal regeneration are highlighted. Amniotic membranes have shown great potential as a suitable substrate/scaffold in in vitro and animal studies; thus provide an alternative for scaffolds materials nowadays. Nevertheless, further studies are required to establish its role and efficacy in periodontal tissue engineering.
\end{abstract}

Keywords: amniotic membrane, periodontal regeneration, scaffold, tissue engineering

Contact: Assoc. Prof. Haslina Taib, M.Clin.Dent.

Periodontics Unit, School of Dental Sciences, Universiti Sains Malaysia, Kubang Kerian, Kelantan 16150, Malaysia.

E-mail: haslinakk@usm.my

This is an open access article under the CC BY-NC-ND license

(http://www.jhsmr.org/index.php/jhsmr/about/editorialPolicies\#openAccessPolicy).

J Health Sci Med Res 2021;39(2):169-180 doi: 10.31584 /jhsmr.2020768 www.jhsmr.org 


\section{Introduction}

Periodontitis is a chronic, inflammatory condition of the periodontium. As it progresses, it will result in the loss of the supporting structures of the tooth; such as alveolar bone, cementum and periodontal ligaments, and eventually leads to tooth loss. ${ }^{1}$

Many non-surgical and surgical interventions are applied to regain the lost integrity of the periodontium. Initially, prophylaxis by scaling and root planing is done to disrupt bacterial accumulation and control the disease. ${ }^{2}$ Upon the severity of periodontal destruction, graft placement, use of growth factors and guided tissue/bone regeneration procedures are performed. However, the true regeneration of this complex tri-phasic interphase of cementum, bone and periodontal ligament has yet to be established. ${ }^{3,4}$

For tissue regeneration, various methods are employed, such as recruiting the hosts own regenerative cells to regenerate the lost structure which is a technique called cell homing. This technique is much slower and depends upon the severity of the damage and hosts regenerative capability. On the other hand, cell based tissue engineering overcomes these problems, as it uses regenerative cells to restore the structures. ${ }^{3}$

Many cell delivery methods have been introduced where the primary purpose is to provide mechanical support and space for cells to grow. ${ }^{5}$ One of these methods is the use of natural and synthetic scaffolds. Cells are seeded onto the scaffold and introduced into the site. Every scaffold has its own, unique properties which makes it suitable for different cell types, and for the site where it is being used. ${ }^{6}$

The only downside to this technique is the use of foreign cells and stability of the cells in the site, for which scaffolds are used. The fabrication of these scaffolds along with seeding of cells on these scaffolds increases the cost and the laboratory time of the procedure.
Those difficulties, mentioned previously, have led to the exploration of cheaper, easily available and biocompatible scaffolds. In so saying the amniotic membrane is one of these scaffolds, which was originally used for dressing wounds and burns. Currently, it has been introduced in periodontal tissue engineering ${ }^{7}$, and its potential as a scaffold has been shown in various in vitro, in vivo and clinical experimental studies, as described in further sections.

Human amniotic membranes (HAM) are the inner most layer of the fetal membrane. It develops from extraembryonic tissue, and has fetal components (the chorionic plate) and maternal components. ${ }^{8}$ HAM is obtained from the placental of mothers, after normal or cesarean deliveries, under informed consent; which is usually obtained without any major ethical issue. ${ }^{9}$ Although, amniotic membranes harvested from normal deliveries pose higher chances of contamination $^{10}$, the donor serum is screened for Hepatitis C antibodies, Hepatitis B surface antigens, Human Immunodeficiency Virus 1 and 2 antibodies and syphilis.

Fresh HAM is processed in the laboratory, for clinical use either in the form of fresh, dried, frozen or cryopreserved. ${ }^{11}$ However fresh HAM has to be used within 24 hours, and may potentially impose slight antigenicity. ${ }^{12}$ Glycerol is the cryoprotective agent that is used for drying the membrane, thus it can be preserved until used. Preserved HAM is more favorable and convenient for clinical application. Nevertheless, the glycerol preserved shows a lack of some growth factors, thus hyper-dry HAM was introduced to overcome this disadvantage. ${ }^{13}$ The method for procurement and decellularization of HAM prior to seeding of specific cells has been reported. ${ }^{14}$

This review is written with the intention of highlighting this biological membrane, which covers the histology of HAM, its medical and dental applications and the potential of HAM as a substrate or scaffold in periodontal 
tissue engineering. A computerized search was performed from databases; PubMed, Scopus, and Google Scholar, by using the keywords: "amniotic membrane", "human amniotic membrane”, "periodontal regeneration”, “periodontal tissue engineering", "scaffold" and "scaffold in periodontal regeneration". All original articles, review articles and case reports published in English, and relevant to the topics were included. In total 61 articles were able to be retrieved and reviewed.

\section{Histology of human amniotic membrane}

The basic structure of HAM consists of a monolayer epithelium, a thick basement membrane and an avascular stroma. ${ }^{15}$ Its thickness varies from $0.02 \mathrm{~mm}$ to $0.5 \mathrm{~mm}$ (Figure 1). The epithelium is a single layer of flat, cuboidal and columnar cells directly in contact with the amniotic fluid (Figure 2). ${ }^{16}$ The stroma (mesenchymal layer) has three sub layers; a compact layer (next to the basement membrane), a fibroblast layer (middle) and a spongy layer. Each layer has certain proteins/factors, which give this membrane its beneficial properties. ${ }^{17}$ The epithelial layer is characterised by: collagen type III and IV, non-collagenous glycoprotein, nidogen, fibronectin, vitronectin, laminin 5, tumor necrosis factor-alpha, nerve growth factor; brain-derived neutrotrophic factor and activin. The basement membrane comprises of integrin a6/ß4 - main ligand. In the stromal (mesenchymal layer), there are various proteins, such as mitogenic protein, anti-angiogenic factors, anti-inflammatory proteins, natural inhibitors to protease and several growth factors. The amniotic membrane does not contain nerves, muscles, or lymphatics; instead, it uses diffusion to transport nutrients from the amniotic fluid and/or from the underlining decidua. $^{8}$
Studies have shown that HAM has anti-inflammatory, anti-scarring, anti-microbial ${ }^{17}$, anti-angiogenic, anti-carcinogenic properties ${ }^{18}$ and the potential as a promoter of epithelialization, additionally it rarely causes immunologic rejection. ${ }^{19}$ These properties along with their mechanism are summarised in Table 1.

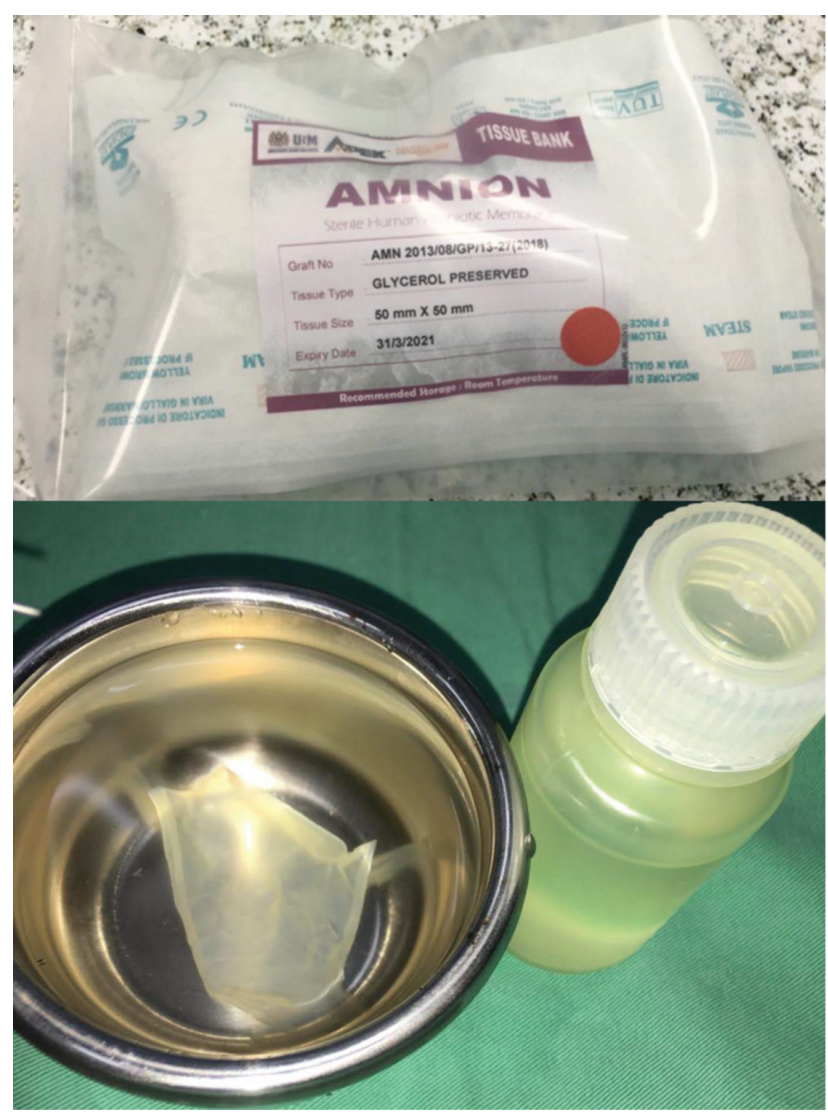

Figure $1 \mathrm{~A}$ human amniotic membrane (Tissue Bank, Universiti Sains Malaysia), preserved by glycerol, was soaked in normal saline before being used. 

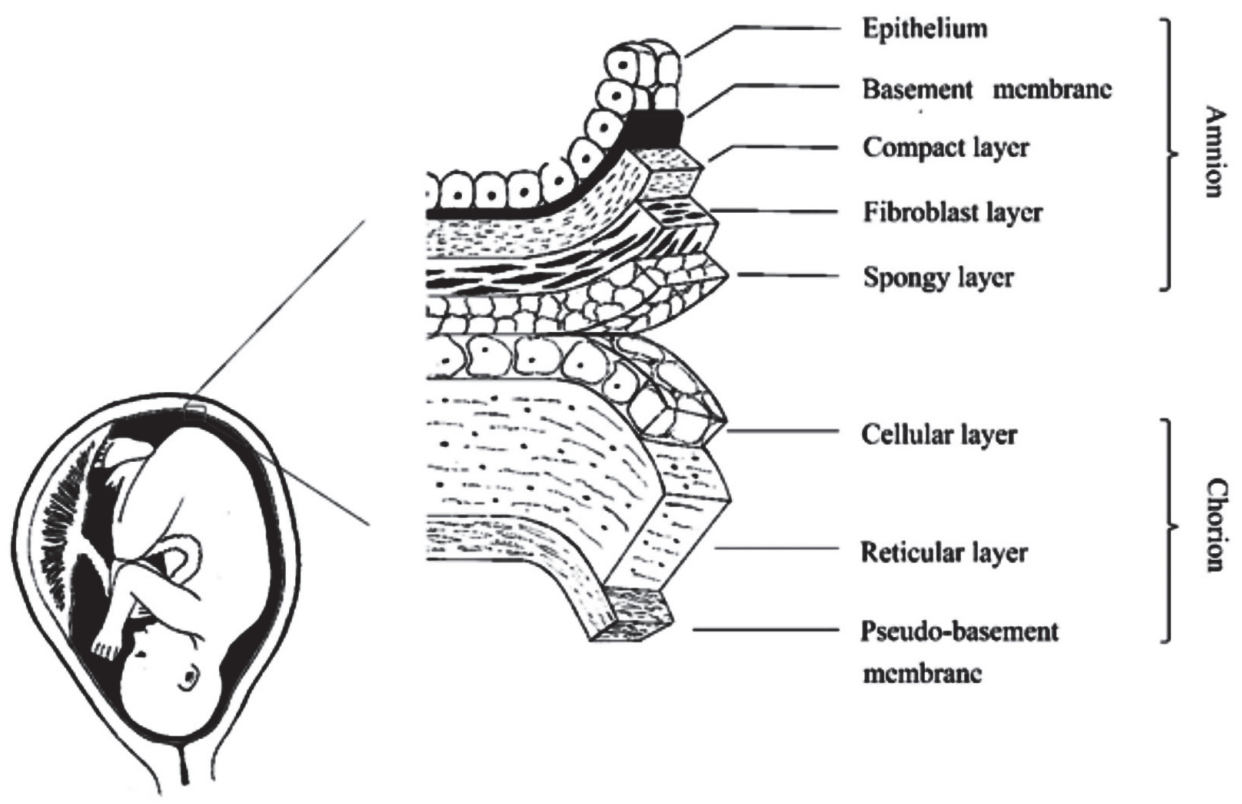

$\left.\begin{array}{l}\text { Cellular layer } \\ \text { Reticular layer } \\ \text { Pseudo-basement }\end{array}\right\}$

membrane

Figure 2 A schematic diagram of a cross section of an amniotic sac. The amniotic sac can be divided into amnion and chorion. The amnion is the inner membrane comprising of the: of epithelium, basement membrane and stromal layer (the stromal layer is comprised of three layers - compact, fibroblast and spongy). While the chorion is the vascular outer membrane that is in contact with the uterine wall, and makes up the rest of the amniotic sac. It consists of a cellular, reticular layer and pseudo-basement membrane. ${ }^{16}$

Table 1 Summary of the properties of human amniotic membranes and their mechanisms ${ }^{22}$

\begin{tabular}{ll}
\hline Properties & Mechanism \\
\hline Promotion of epithelialization & Amniotic membranes act as a substrate, on which epithelial cells grow on by facilitating the following: \\
& 1) Epithelial cell migration \\
2) Basal epithelial cell adhesion \\
3) Epithelial cell differentiation \\
4) Prevention of apoptosis \\
\hline 1) Fetal hyaluronic acid suppresses TGF- $\beta$ signaling (reduced expression of TGF- $\beta 1$, TGF- $\beta 2$, and \\
TGF- $\beta 3$ isoforms and reduced expression of TGF-Receptor II), inhibiting proliferation of fibroblasts. \\
2) Inhibition of differentiation of fibroblasts into myofibroblasts \\
1) Chemical mediated anti-inflammatory effect \\
Inhibiting proinflammatory cytokines: \\
IL-la, IL-2, IL-8, Interferon- $\gamma$, Tumor Necrosis Factor- $\beta$, basic fibroblast growth factor, platelet \\
derived growth factor \\
2) Mechanical effect: \\
Entrapment of inflammatory cells \\
Apoptosis of inflammatory cells in matrix of amniotic membrane
\end{tabular}


Table 1 (continued)

\begin{tabular}{|c|c|}
\hline Properties & Mechanism \\
\hline Anti-angiogenic & $\begin{array}{l}\text { Anti-angiogenic chemicals are present or secreted: } \\
\text { 1) Thrombospondin-1 } \\
\text { 2) Endostatin } \\
\text { 3) Tissue inhibitors of metalloproteases-1, }-2,-3,-4 \\
\text { 4) Heparin sulphate proteoglygan }\end{array}$ \\
\hline Anti-microbial & $\begin{array}{l}\text { 1) Presence of anti-microbial factors: } \\
\text { a. Bactricidiin } \\
\text { b. Beta-lysin } \\
\text { c. Lysozyme } \\
\text { d. Transferin } \\
\text { e. } 7 \text { S immunoglobulin } \\
\text { 2) Acts as a physical barrier as human amniotic membranes closely adhere to underlying structures }\end{array}$ \\
\hline Immunomodulative & $\begin{array}{l}\text { There is no immune rejection from human amniotic membranes, as it lacks histocompatibility antigens } \\
\text { such as HLA-A, HLA-B or HLA-DR }\end{array}$ \\
\hline Anti-carcinogenic & $\begin{array}{l}\text { 1) Anti-angiogenesis: prevents tumor growth and metastasis of cancer cells } \\
\text { 2) Pro-apoptosis } \\
\text { 3) Cell cycle arrest }\end{array}$ \\
\hline
\end{tabular}

TGF- $\beta=$ transforming growth factor-beta, IL=Interleukin, HLA=human leukocyte antigen

\section{Medical and dental applications of human amniotic membranes}

Amniotic membranes have long been utilized in traditional Chinese medicine, but its first scientific documentation was conducted as a skin substitute. ${ }^{20}$ Since then, HAM has been used in many medical procedures. The summary of some, various medical applications of this membrane is shown in Table 2. In the management of burns, HAM is used as a biological dressing substitute for skin grafts (amnioplasty). ${ }^{21}$ Due to its low immunogenicity, anti-inflammatory and anti-bacterial effects, re-epithelialization of the skin epithelium has rapidly occurred, without invasive bacterial infection. ${ }^{22}$

A few procedures in ophthalmology have successfully utilized HAM, including treatment for corneal surface disorder, conjunctival surface reconstruction, as a carrier for ex vivo expansion of corneal epithelial cells, non-healing ulcers and glaucoma. ${ }^{22}$ It acts as a mechanical support, and protects the regenerating ocular epithelium from frictional forces in cases that involve damaged epithelium. HAM also promotes re-epithelialization of the host ocular epithelium; thus, accelerating the healing process, especially in cases of non-healing ulcers or persistent epithelial defects of the ocular surface. This is attributed to its basement membrane that is similar to the collagen composition of the conjunctiva and cornea. ${ }^{20}$ Other medical usage of HAM include: diabetic foot ulcers $^{23}$, temporalis fascia grafts ${ }^{24}$, reconstruction of dura mater ${ }^{25}$, repair of myelomeningocele ${ }^{26}$ and vaginoplasty. ${ }^{27}$ These studies reported that the healing process was uneventful, reduced scarring and inflammation. This reflects that HAM possessed a non-fibrillar meshwork, mainly collagen type III, and provided a suitable condition for cell growth. ${ }^{28}$

The use of HAM in dentistry has been reported in only a few studies and/or case reports. Amniotic membranes were used in maxillofacial surgery by Kothary in 1969, for 
Table 2 Different medical applications, and the use of amniotic membranes

\begin{tabular}{|c|c|c|}
\hline Applications & Procedures & Benefit \\
\hline Burns $^{21}$ & Dressings & $\begin{array}{l}\text { Acts as a barrier to bacterial colonization } \\
\text { and re-epithelializes the skin while } \\
\text { controlling water loss. }\end{array}$ \\
\hline Ophthalmology ${ }^{22}$ & $\begin{array}{l}\text { 1) Corneal surface disorders, without limbal stem cell deficiency, } \\
\text { 2) Corneal surface disorders associated limbal stem cell deficiency } \\
\text { 3) Conjunctival surface reconstruction } \\
\text { 4) As a carrier for ex vivo expansion of corneal epithelial cells } \\
\text { 5) Glaucoma } \\
\text { 6) Treatment of sclera melts and perforations }\end{array}$ & $\begin{array}{l}\text { 'Biological bandage contact lens' to } \\
\text { preventing friction from being generated } \\
\text { by the moving eyelid. }\end{array}$ \\
\hline $\begin{array}{l}\text { Reconstructive } \\
\text { surgery }^{27,56,57}\end{array}$ & $\begin{array}{l}\text { Vaginoplasty } \\
\text { Bladder } \\
\text { Tympanoplasty } \\
\text { Arthroplasty }\end{array}$ & \\
\hline
\end{tabular}

mouth floor reconstruction after a glossectomy. ${ }^{29}$ HAM was compared with platelet-rich fibrin (PRF) for management of Miller Class I gingival recession defect, and demonstrated that the site treated with HAM achieved stable, ful root coverage comparable to PRF treated sites after seven months. ${ }^{30}$ This suggested HAM could be considered as a superior material, owing to laboratory preparation for PRF. Furthermore Shah et al. ${ }^{31}$ also showed complete root coverage of a Miller Class II gingival recession associated with enhanced tissue architecture after a six month review in a 32-year-old patients treated with HAM. In another clinical trials, HAM was used for root coverage procedures in 22 patients, with a total of 71 teeth that demonstrated significant changes of the recessions defect and gingival width compared to the baseline. It was also associated with significant improvement of the clinical attachment and probing depths. ${ }^{32}$ Other, previous reports, as summarized in Table 3, also support that amnion allograft might be a suitable, alternative biomaterial in procedures to cover denuded root surfaces. This will avoid separate surgical sites for harvesting tissue graft, thus reducing patient morbidity and discomfort.
HAM has also been used as a dressing for intraoral, exposed defect surfaces. ${ }^{33}$ It was used to cover the exposed bone surface of the alveolar ridge, following resection of the white lesion. HAM, in the form of hyperdry, showed good adherence over the wound and promoted epithelialization, which was observed after approximately six weeks: no recurrence of the lesion was reported after 18 months. ${ }^{33}$ A similar result was also demonstrated in another case, reported by the same authors, for the management of vestibuloplasty in which sufficient keratinized tissue has been obtained after being grafted with $\mathrm{HAM}^{33}$ Neither rejection, nor any excessive inflammatory reaction towards HAM was reported. HAM proved to act as an anatomic barrier ${ }^{34}$, and possessed several unique characteristics, such as a lack of immunogenicity and anti-inflammatory effects; thus promoting the healing process. Apart from promising effects on wound healing, HAM also displayed effective outcomes for facial nerve repair in rat models. ${ }^{35}$ These studies showed that HAM grafts appeared to produce better results for oral tissue reconstruction in comparison to other grafts, such as split skin graft, alloderm and buccal fat pad flap, that showed some shrinkage, contraction and rejection. ${ }^{36}$ 
Table 3 Studies on amniotic membranes, as guided tissue regeneration membranes in periodontal surgeries

\begin{tabular}{|c|c|c|c|c|}
\hline Type of study & Materials & Subjects & Outcome & References \\
\hline Case report & $\begin{array}{l}\text { Amniotic membrane vs } \\
\text { platelet-rich fibrin }\end{array}$ & $\begin{array}{l}40 \text { year-old } \\
\text { male }\end{array}$ & $\begin{array}{l}\text { Stable and ful root coverage of a Miller Class } \\
\text { I gingival recession defect, after seven months } \\
\text { post-surgery in both groups }\end{array}$ & 30 \\
\hline Case report & $\begin{array}{l}\text { Amniotic allograft in } \\
\text { conjunction with gingival } \\
\text { flap }\end{array}$ & $\begin{array}{l}32 \text { year-old } \\
\text { female }\end{array}$ & $\begin{array}{l}\text { Complete root coverage of a Miller Class II } \\
\text { gingival recession associated with enhanced } \\
\text { tissue architecture, after six months post-surgery }\end{array}$ & 31 \\
\hline $\begin{array}{l}\text { Double blind } \\
\text { randomized } \\
\text { control clinical } \\
\text { trial }\end{array}$ & $\begin{array}{l}\text { Amniotic membrane vs } \\
\text { connective tissue graft }\end{array}$ & $\begin{array}{l}71 \text { teeth in } 22 \\
\text { human patients }\end{array}$ & $\begin{array}{l}\text { Significant changes of the recessions defect } \\
\text { and gingival width from the baseline. Clinical } \\
\text { attachment level and probing depths were } \\
\text { improved significantly in the group treated with } \\
\text { amniotic membrane, after six months }\end{array}$ & 32 \\
\hline Case report & $\begin{array}{l}\text { Placental chorion } \\
\text { membrane }\end{array}$ & $\begin{array}{l}56 \text { year-old } \\
\text { male }\end{array}$ & $\begin{array}{l}\text { Complete root coverage and changes of thin to } \\
\text { thick tissue biotype were observed three months } \\
\text { after surgery }\end{array}$ & 58 \\
\hline $\begin{array}{l}\text { Retrospective } \\
\text { observational } \\
\text { report }\end{array}$ & Amnion chorion allograft & 64 patients & $\begin{array}{l}\text { Reduction of probing pocket depth and gain in } \\
\text { clinical attachment level, twelve months after } \\
\text { surgery }\end{array}$ & 59 \\
\hline Case series & Amniotic membrane & 3 patients & $\begin{array}{l}\text { Significant improvement of the clinical attachment } \\
\text { level and width of keratinized gingiva, six months } \\
\text { postoperative }\end{array}$ & 60 \\
\hline
\end{tabular}

Infection control is particularly important to ensure the success of post-surgical sites. Amniotic membranes may help against microbial colonization, thus preventing infection by secretion of the anti-microbial peptides, such as beta defensins, secretory leukocyte proteinase inhibitor and elafin. The amniotic cells also secrete large amounts of cystatin $E$, an analogue of cysteine proteinase inhibitors, giving antiviral properties to the amniotic membrane. ${ }^{37-39}$ Moreover, a lack of post-operative pain has been reported when using HAM, which could be owing to its antiinflammatory effect and the ability to protect the nerve endings from external irritants. ${ }^{40}$

Through the advancement in clinical and laboratory techniques, HAM is now being used as a membrane in guided tissue regenerative procedures, substrate for culturing stem cells and as scaffolds for delivering regenerative cells into oral defects (Table 4). ${ }^{11,14}$

\section{Potential of HAM as a substrate, or scaffold in periodontal tissue engineering}

Periodontium is a complex tri-phasic structure, comprised of soft (gingiva, periodontal ligament) and hard tissues (alveolar bone, cementum). In advanced periodontal disease, destruction and loss of these structures may lead to the formation of bone defects, due to active interactions between microbial infections and host inflammatory responses; in which tooth loss is the definitive complication. The ultimate goal of periodontal therapy is to restore the loss of periodontal architecture, and functions by which are unpredictable to be achieved with conventional periodontal therapy alone. Therefore, regeneration of the periodontal attachment apparatus became a significant procedure to reconstitute original tissue. ${ }^{41}$

Several regenerative approaches as well as materials are well documented in the literatures. Guided 
Table 4 Amniotic membranes as substrate/scaffolds, for periodontal progenitor/stem cells

\begin{tabular}{|c|c|c|c|c|}
\hline Type of study & Substrate/scaffold & Cells & Outcome & References \\
\hline In-vitro & Amniotic membrane & $\begin{array}{l}\text { Human periodontal } \\
\text { ligament cell sheets }\end{array}$ & $\begin{array}{l}\text { Cells were able to differentiate, proliferate } \\
\text { and express the essential proteins for cell- } \\
\text { substrate adhesion }\end{array}$ & 9 \\
\hline In-vitro & Amniotic membrane & $\begin{array}{l}\text { Periosteal-derived cell } \\
\text { sheet }\end{array}$ & $\begin{array}{l}\text { Amniotic membranes showed good adhesion } \\
\text { with periosteal-derived cell sheet }\end{array}$ & 51 \\
\hline In-vitro & Amniotic membrane & $\begin{array}{l}\text { Human dental pulp- } \\
\text { derived cells }\end{array}$ & $\begin{array}{l}\text { Amniotic membranes showed good adhesion } \\
\text { to dental pulp-derived cell sheet }\end{array}$ & 61 \\
\hline $\begin{array}{l}\text { Pre-clinical } \\
\text { (rat model) }\end{array}$ & Amniotic membrane & $\begin{array}{l}\text { Periodontal ligament } \\
\text { stem cells }\end{array}$ & $\begin{array}{l}\text { Periodontal regeneration was enhanced and } \\
\text { showed a monolayer of the cells on the } \\
\text { amnion surface }\end{array}$ & 52 \\
\hline $\begin{array}{l}\text { In-vivo } \\
\text { (rat model) }\end{array}$ & Amniotic membrane & $\begin{array}{l}\text { Adipose-derived stem } \\
\text { cells }\end{array}$ & $\begin{array}{l}\text { Periodontal regeneration was enhanced in } \\
\text { the surgically created bone defect }\end{array}$ & 54 \\
\hline
\end{tabular}

tissue regeneration (GTR) has been greatly applied in regenerative procedures, by using the barrier membrane to allow the repopulation of periodontal ligament cells from the defect area. ${ }^{42}$ However, the unpredictable clinical outcome and effectiveness of GTR have been reported, although attempts have also been made by using bioactive molecules; such as enamel matrix derivative and growth factors, including platelet-derived growth factors to promote regeneration. ${ }^{4,43}$ Periodontal tissue engineering has been addressed for regenerating complex periodontal structures, utilizing scaffolds cultured with specific cells, adding bioactive molecules in the laboratory; followed by surgically implantation at the defect sites. ${ }^{44}$ Progenitor cells such as periodontal ligament stem cells or other cells; including mesenchymal stem cells, were cultured on a scaffolds to form a 3D tissue-engineering model before being inserted into the periodontal defect area. ${ }^{45}$ The characteristics of the scaffold are important to support cell proliferation and differentiation, allowing for the ingrowth of cells as well as being able to facilitate revascularization following implantation. This multiphasic scaffold has to remain intact during the maturation of the tissues, prior to undergoing the biodegradation process. ${ }^{46}$
Scaffold can be categorized into biological (natural) and synthetic scaffolds. Biological scaffolds derived from human and animal tissues; such as HAM, chitosan, hyaluronic acid and cellulose, whereas hydroxyapatite $(\mathrm{HA})$, tricalcium phosphate, polyglycolic acid, and polylactic acid are among the synthetic scaffolds available on the market. Natural scaffolds are readily available, and offer a less expensive alternative to synthetic scaffolds. Furthermore, biological scaffolds provide specific cell interaction, biocompatible, tissue-like characteristic that are highly acceptable by host tissues. ${ }^{47}$ Chitosan is biocompatible, able to be degraded by human enzymes, and widely used for natural scaffolds. ${ }^{48}$ However, it is often combined with other bioactive materials, such as $\mathrm{HA}$, to improve its bioactivity in bone tissue engineering. Recently chitosan gel has been incorporated with alkaline phosphatase to promote bone mineralization. ${ }^{49,50}$ Owing to being easily available and a relatively inexpensive material, HAM became an alternative scaffold for tissue engineering.

Good cell-cell adhesion was observed among periodontal ligament stem cells (PDLSCs) ${ }^{9}$ and periosteal cells when they were cultured on $\mathrm{HAM}^{51}$ These studies suggest that amniotic membranes can be used as a 
substrate for the cultivation of PDLSCs. Another study has demonstrated the application of amniotic membranes as a scaffold using PDLSCs in rat periodontal models. ${ }^{52}$ This membrane can be closely adapted to the underlying periodontal structures, because of its thin, cross-sectional dimension. ${ }^{31}$ HAM also has the advantage of mimicking the gingival tissues by having a basement membrane, which synthetic scaffolds lack. Thus, HAM is a suitable scaffold for in vitro studies. ${ }^{17}$ It also has other benefits for in vivo studies, because of its biological properties.

In a recent study, HAM provided good biocompatibility for the attachment and proliferation of human periodontal ligament fibroblast cells. Even though there were some limitations, noted by the authors, the results could be a basis for future works on HAM as scaffold for periodontal tissue engineering. ${ }^{14}$ It is known that for periodontal regeneration, the success of autologous ex vivo expanded cells culture depends on the substrate used, and whether it could induce cell attachment or proliferation of progenitors/stem cells. Therefore, as a substrate or scaffold, HAM was shown to be compatible for periodontal cell growth, as evidenced by the ability of cells to penetrate the matrix. ${ }^{9}$ The study also demonstrated that the essential proteins for cell-substrate adhesion as well as for maintaining tissue integrity; such as laminin 5, laminin alpha 5 chain, collagen IV, and collagen VII, were expressed. ${ }^{9}$ Other studies on HAM, using PDLSCs, also showed the expression of cell-cell adhesion proteins. ${ }^{52,53}$ In addition, periosteal cells interacting with HAM showed expressions of cell proliferation (Ki-67), mesenchymal cell (vimentin), and osteoblast markers (Gla protein). ${ }^{51}$ The cells also expressed desmoplakin (desmosomal proteins) and ZO-1 (tight junction proteins). ${ }^{51}$ The previously mentioned studies prove the potential of HAM as a culturing cell sheets substrate.

In vivo studies also showed the promising data of HAM. A transplanted PDLSC-HAM into the surgically created periodontal defects at first maxillary molars for 4 weeks, showed enhanced periodontal regeneration, and a monolayer of PDLSCs on the amnion surface, respectively. ${ }^{52}$ A similar finding was shown when a construct, consisting of adipose derived stem cells and HAM, was transplanted into a surgically created two wall infrabony defects. ${ }^{54}$

Despite successful uses of HAM, reported from vast literatures, some limitations of this membrane have to be taken into account. In ophthalmology, early detachment and premature degradation of HAM at the operative site has been reported; forcing the need of repeated transplantation. ${ }^{22}$ Principally, in tissue engineering, scaffolds should be biocompatible, stable and biodegradable during appropriate periods of time, for the homing of the cells at the target site, allowing complete maturation of the regenerative tissue. However, the quick degradation of HAM, due to endogenous enzymes, may be insufficient for implant sites that require longer scaffold stability and strength. ${ }^{22}$ Moreover, although HAM is a transparent structure, that offers clear visibility of the underlying wound when apply over the tissue defect ${ }^{33}$, this membrane is very delicate and thin in dimension; which also gives it a disadvantage when reconstructing 3D defects. ${ }^{16}$ It was suggested that treating HAM with crosslinking agents; such as genipin, formaldehyde or glutaraldehyde, may improve HAM's biostability and mechanical strength. ${ }^{28}$ Physical treatment; such as ultraviolet, gamma ray and electron beam irradiation, have also been used to enhance the stability of HAM. ${ }^{14}$ There is a need of further investigation to overcome these shortcomings of HAM, mainly in the field of periodontal tissue engineering.

As described by a previous report, multiphasic scaffolds for periodontal tissue engineering should possess compartmentalized bone and periodontal attachment tissue formation, enhance cementum formation, and reconstitute the periodontal ligament fibers; that are functionally oriented into the newly regenerated alveolar bone and cementum. ${ }^{55}$ The potential of HAM, as carryings 
of this criteria, require further research in vitro and in vivo. Nevertheless, with the current findings on the superiority of HAM histologically as well as clinically that are comparable with the current, available scaffolds for tissue engineering is a promising, alternative biomaterial in the management of periodontal defects. ${ }^{14,22,36}$

\section{Conclusion}

Amniotic membranes are being used in a wide range of procedures and disciplines in medicine, dentistry and stem cell research, owing to its pleiotropic properties and having the advantage of being a biological membrane. Amniotic membranes have shown great potential as suitable scaffolds, and therefore, can serve as an alternative material in periodontal tissue regeneration and engineering. Further clinical studies are required to establish its role and efficacy.

\section{Acknowledgement}

This review is supported by Universiti Sains Malaysia Research University Grant (1001/PPSG/ 8012283).

\section{Conflict of interest}

All authors declare no conflict of interest.

\section{References}

1. Han J, Menicanin D, Gronthos S, Bartold PM. Stem cells, tissue engineering and periodontal regeneration. Aust Dent J 2014;59(Suppl 1):S117-30.

2. Worthington HV, Clarkson JE, Bryan G, Beirne PV. Routine scale and polish for periodontal health in adults. Cochrane Database of Syst Rev 2013;11:3-59.

3. Chen FM, Sun HH, Lu H, Yu Q. Stem cell-delivery therapeutics for periodontal tissue regeneration. Biomaterials 2012;33:6320-44.

4. Kao RT, Nares S, Reynolds MA. Periodontal regenerationintrabony defects: a systematic review from the AAP Regeneration Workshop. J Periodontol 2015;86:S77-104.
5. Padial-Molina M, Rios HF. Stem cells, scaffolds and gene therapy for periodontal engineering. Curr Oral Heal Reports 2013;1:16-25.

6. Dabra S, Chhina K, Soni N, Bhatnagar R. Tissue engineering in periodontal regeneration: a brief review. Dent Res $J$ (Isfahan) 2012;9:671-80.

7. Litwiniuk M, Grzela T. Amniotic membrane: new concepts for an old dressing. Wound repair Regen 2014;22:451-6.

8. Agarwal A, Shankar S, Singh G. P leiotropic $P$ roperties of A mniotic $M$ embrane for $M$ odulation of $P$ eriodontal $H$ ealing. Int J Dent Med Res 2014;1:110-7.

9. Adachi K, Amemiya T, Nakamura T, Honjyo K, Kumamoto S, Yamamoto $T$, et al. Human periodontal ligament cell sheets cultured on amniotic membrane substrate. Oral Dis 2014;20: 582-90.

10. Mahmoudi-Rad M, Abolhasani E, Moravvej H, Mahmoudi-Rad N, Mirdamadi Y. Acellular amniotic membrane: an appropriate scaffold for fibroblast proliferation. Clin Exp Dermatol 2013;38: 646-51.

11. Mohan R, Bajaj A, Gundappa M. Human Amnion Membrane: Potential Applications in Oral and Periodontal Field. J Int Soc Prev Community Dent 2017;7:15-21.

12. Qi F, Yoshida T, Koike T, Aizawa H, Shimane T, Li Y, et al. Construction and characterization of human oral mucosa equivalent using hyper-dry amniotic membrane as a matrix. Arch Oral Biol 2016;65:26-34.

13. Okabe M, Kitagawa K, Yoshida T, Suzuki T, Waki H, Koike $C$, et al. Hyperdry human amniotic membrane is useful material for tissue engineering: physical, morphological properties, and safety as the new biological material. J Biomed Mater Res A 2014;102:862-70.

14. Elahi A, Taib H, Berahim Z, Azlina A, Ab Hamid SS. Evaluation of the Human Amniotic Membrane as a Scaffold for Periodontal Ligament Fibroblast Attachment and Proliferation. Sains Malays 2019;48:1927-35.

15. Niknejad H. Properties of the amniotic membrane for potential use in tissue engineering. Eur Cells Mater 2008;15:88-99.

16. Elahi A. Evaluation of human amniotic membrane as a scaffold for periodontal tissue engineering: an in vitro study [monograph on the Internet]. Kubang Kerian: Universiti Sains Malaysia; 2017 [cited 2020 Apr 13]. Available from: http://hdl. handle.net/123456789/7099 
17. Chopra A, Thomas BS. Amniotic membrane: a novel material for regeneration and repair. J Biomim Biomater Tissue Eng 2013;18:1-8.

18. Niknejad H, Khayat-Khoei M, Peirovi H, Abolghasemi H. Human amniotic epithelial cells induce apoptosis of cancer cells: a new anti-tumor therapeutic strategy. Cytotherapy 2014;16:3340.

19. Mamede AC, Carvalho MJ, Abrantes AM, Laranjo M, Maia CJ, Botelho MF. Amniotic membrane: from structure and functions to clinical applications. Cell Tissue Res 2012;349:44758

20. Davis JW. Skin transplantation with a review of 550 cases at the Johns Hopkins Hospital. Johns Hopkins Med J 1910;15: 307.

21. Andonovska D, Dzokic G, Spasevska L, Trajkovska T, Popovska K, Todorov I, et al. The advantages of the application of amnion membrane in the treatment of burns. Prilozi 2008 ; 29:183-98.

22. Malhotra C, Jain AK. Human amniotic membrane transplantation: different modalities of its use in opthalmology. World J Transplant 2014;4:111-21.

23. Zelen CM, Serena TE, Snyder RJ. A prospective, randomised comparative study of weekly versus biweekly application of dehydrated human amnion/chorion membrane allograft in the management of diabetic foot ulcers. Int Wound J 2014;11: 122-8.

24. Shojaku H, Takakura H, Okabe M, Fujisaka M, Watanabe $Y$, Nikaido T. Effect of hyperdry amniotic membrane patches attached over the bony surface of mastoid cavities in canal wall down tympanoplasty. Laryngoscope 2011;121: 1953-7.

25. Tomita T, Hayashi N, Okabe M, Yoshida T, Hamada H, Endo S, et al. New dried human amniotic membrane is useful as a substitute for dural repair after skull base surgery. J Neurol Surg B Skull Base 2012;73:302-7.

26. de Weerd L, Weum S, Sjavik K, Acharya G, Hennig RO. A new approach in the repair of a myelomeningocele using amnion and a sensate perforator flap. J Plast Reconstr Aesthet Surg 2013;66:860-3.

27. Sarwar I, Sultana R, Nisa RU, Qayyum I. Vaginoplasty by using amnion graft in patients of vaginal agenesis associated with Mayor-Rokitansky-Kuster-Hauser syndrome. J Ayub Med Coll Abbottabad 2010;22:7-10.
28. Gobinathan S, Zainol SS, Azizi SF, Iman NM, Muniandy R, Hasmad HN, et al. Decellularization and genipin crosslinking of amniotic membrane suitable for tissue engineering applications. J Biomater Sci Polym Ed 2018;29:2051-67.

29. Kothary PM. Preliminary report on the use of amniotic membrane as a graft after extensive oropharyngeal surgery. Indian J Med Sci 1969;23:329.

30. Shetty SS, Chatterjee A, Bose S. Bilateral multiple recession coverage with platelet-rich fibrin in comparison with amniotic membrane. J Indian Soc Periodontol 2014;18:102-6.

31. Shah R, Sowmya NK, Mehta DS. Amnion membrane for coverage of gingival recession: a novel application. Contemp Clin Dent 2014;5:293-5.

32. Ghahroudi AAR, Khorsand A, Rokn AR, Sabounchi SS, Shayesteh YS, Soolari A. Comparison of amnion allograft with connective tissue graft for root coverage procedures: a double-blind, randomized, controlled clinical trial. J Int Acad Periodontol 2013;15:101-12.

33. Tsuno H, Arai N, Sakai C, Okabe M, Koike C, Yoshida T, et al. Intraoral application of hyperdry amniotic membrane to surgically exposed bone surface. Oral Surg Oral Med Oral Pathol Oral Radiol 2014;117:e83-7.

34. Kitagawa K, Yanagisawa S, Watanabe K, Yunoki T, Hayashi A, Okabe $\mathrm{M}$, et al. A hyperdry amniotic membrane patch using a tissue adhesive for corneal perforations and bleb leaks. Am J Ophthalmol 2009;148:383-9.

35. Karaman M, Tuncel A, Sheidaei S, Senol MG, Karabulut $\mathrm{MH}$, Deveci I, et al. Amniotic membrane covering for facial nerve repair. Neural Regen Res 2013;8:975-82.

36. Kar IB, Singh AK, Mohapatra PC, Mohanty PK, Misra S. Repair of oral mucosal defects with cryopreserved human amniotic membrane grafts: prospective clinical study. Int J Oral Maxillofac Surg 2014;43:1339-44.

37. Pacora P, Maymon E, Gervasi MT, Gomez R, Edwin SS, Yoon $\mathrm{BH}$, et al. Lactoferrin in intrauterine infection, human parturition, and rupture of fetal membranes. Am J Obstet Gynecol 2000;183:904-10.

38. Buhimschi IA, Jabr M, Buhimschi CS, Petkova AP, Weiner CP, Saed GM. The novel antimicrobial peptide $\beta 3$-defensin is produced by the amnion: a possible role of the fetal membranes in innate immunity of the amniotic cavity. Am $\mathrm{J}$ Obstet Gynecol 2004;191:1678-87.

39. King AE, Paltoo A, Kelly RW, Sallenave JM, Bocking AD 
Challis JR. Expression of natural antimicrobials by human placenta and fetal membranes. Placenta 2007;28:161-9.

40. Pires RT, Tseng SC, Prabhasawat P, Puangsricharern V, Maskin SL, Kim JC, et al. Amniotic membrane transplantation for symptomatic bullous keratopathy. Arch Ophthalmol 1999; 117:1291-7.

41. Caton J, Nyman S, Zander H. Histometric evaluation of periodontal surgery II. Connective tissue attachment levels after four regenerative procedures. J Clin Periodontol 1980;7:224-31.

42. Karring T, Nyman S, Gottlow JA, Laurell L. Development of the biological concept of guided tissue regenerationanimal and human studies. Periodontol 2000 1993;1:26-35.

43. Esposito M, Grusovin MG, Papanikolaou N, Coulthard P, Worthington HV. Enamel matrix derivative (Emdogain $\AA$ ) for periodontal tissue regeneration in intrabony defects. A Cochrane systematic review. Eur J Oral Implantol 2009;2:24766.

44. Bartold PM, Mcculloch CA, Narayanan AS, Pitaru S. Tissue engineering: a new paradigm for periodontal regeneration based on molecular and cell biology. Periodontol 2000 2000; 24:253-69.

45. Bartold PM, Xiao Y, Lyngstaadas SP, Paine ML, Snead ML. Principles and applications of cell delivery systems for periodontal regeneration. Periodontol 2000 2006;41:123-35.

46. Lam CX, Hutmacher DW, Schantz JT, Woodruff MA, Teoh $\mathrm{SH}$. Evaluation of polycaprolactone scaffold degradation for 6 months in vitro and in vivo. J Biomed Mater Res A 2009;90: 906-19.

47. Wang $M$, Yoshida A, Kawashima $H$, Ishizaki M, Takahashi $H$, Hori J. Immunogenicity and antigenicity of allogeneic amniotic epithelial transplants grafted to the cornea, conjunctiva, and anterior chamber. Invest Ophthalmol Vis Sci 2006;47:152232.

48. Kong L, Gao Y, Lu G, Gong Y, Zhao N, Zhang X. A study on the bioactivity of chitosan/nano-hydroxyapatite composite scaffolds for bone tissue engineering. Eur Polym J 2006;42: 3171-9.

49. Douglas TE, Krok-Borkowicz MA, Macuda A, Pietryga K, Pamuła EL. Enrichment of thermosensitive chitosan hydrogels with glycerol and alkaline phosphatase for bone tissue engineering applications. Acta Bioeng Biomech 2016;18:51-7.

50. Skwarczynska AL, Binias D, Maniukiewicz W, Modrzejewska $Z$, Douglas TEL. The mineralization effect on chitosan hydro- gel structure containing collagen and alkaline phosphatase. J Mol Struct 2019;1187:86-97.

51. Amemiya $\mathrm{T}$, Honjo KI, Adachi K, Nishigaki M, Oseko F, Yamamoto $T$, et al. Immunohistochemical study of periostealderived cell sheet cultured on amniotic membrane aiming at periodontal tissue regeneration. J Oral Maxillofac Surg 2014; 72:e176.

52. Iwasaki K, Komaki M, Yokoyama N, Tanaka Y, Taki A, Honda I, et al. Periodontal regeneration using periodontal ligament stem cell-transferred amnion. Tissue Eng Part A 2014;20:693704.

53. Liu Y, Zheng Y, Ding G, Fang D, Zhang C, Bartold PM, et al. Periodontal ligament stem cell-mediated treatment for periodontitis in miniature swine. Stem Cells 2008;26:1065-73.

54. Wu PH, Chung HY, Wang JH, Shih JC, Kuo MY, Chang PC, et al. Amniotic membrane and adipose-derived stem cell co-culture system enhances bone regeneration in a rat periodontal defect model. J Formos Med Assoc 2016;115:186-94.

55. Ivanovski S, Vaquette C, Gronthos S, Hutmacher DW, Bartold PM. Multiphasic scaffolds for periodontal tissue engineering. J Dent Res 2014;93:1212-21.

56. Rennie K, Gruslin A, Hengstschläger M, Pei D, Cai J, Nikaido T, et al. Applications of amniotic membrane and fluid in stem cell biology and regenerative medicine. Stem Cells Int 2012. doi.org/10.1155/2012/721538.

57. Sheta E, Elzomor S, Eltookhy O, Elkader NAA, Ahmed KA. Structural and functional renovation of urinary bladders after amniotic membrane implantation in dogs. Int $\mathrm{J}$ Vet Sci Med 2014;2:57-66.

58. Suresh DK, Gupta A. Gingival biotype enhancement and root coverage using human placental chorion membrane. Clin Adv Periodontics 2013;3:237-42.

59. Holtzclaw DJ, Toscano NJ. Amnion-chorion allograft barrier used for guided tissue regeneration treatment of periodontal intrabony defects: a retrospective observational report. Clin Adv Periodontics 2013;3:131-7.

60. Sharma A, Yadav K. Amniotic membrane - A Novel material for the root coverage: a case series. J Indian Soc Periodontol 2015;19:444-8.

61. Honjo KI, Yamamoto T, Oseko F, Amemiya T, Kita M, Mazda O, et al. Examination of bone differentiation for human dental pulp-derived cells cultured on amniotic membrane. J Oral Maxillofac Surg 2014;72:e178-9. 